\title{
Fossil Vertebrate Database from Cova des Pas de Vallgornera (Llucmajor, Mallorca)
}

\author{
Anna Diaz ${ }^{1 *}$, Pere Bover ${ }^{2}$, and Josep Antoni Alcover ${ }^{2 *}$ \\ ${ }^{1}$ Freelance biologist, Sineu, Mallorca, Spain \\ ${ }^{2}$ IMEDEA (UIB-CSIC), C/Miquel Marquès, 21, 07190, Esporles, Spain
}

\begin{abstract}
The data set presented in this paper includes the fossil fauna collected in the cave named Cova des Pas de Vallgornera (CPV), located on the southern coast of Mallorca (Balearic Islands, Spain). It holds 1481 catalogued items, $97.5 \%$ identified at species level. Mammalia, Aves, Reptilia, and Amphibia are represented in the Database. The fauna collected in the cave includes the three endemic mammals present on Mallorca during the Early Pleistocene (Myotragus aff. kopperi, Hypnomys onicensis, and Nesiotites aff. ponsi). There are also represented two taxa of Chiroptera (Rhinolophus aff. mehelyi and Pipistrellus sp.), 16 taxa of birds ( 6 of them identified at species level), one Reptilian taxon (Podarcis sp.), and one Amphibian taxon (Discoglossus sp.). Most fossils were collected during a single excavation campaign of 3 days (28-30 th May, 2010). A few remains were obtained in two previous visits to the cave, in 2006 and 2009. All the specimens are curated and documented at the Vertebrate Collection of the IMEDEA [Institut Mediterrani d'Estudis Avançats (CSIC-UIB)]. The assemblage of CPV fossils is a part of the paleontological collection IMEDEA-PALEOVERT, included at the GBIF portal.
\end{abstract}

Keywords: fossil vertebrates; Cova des Pas de Vallgornera; Myotragus; Myotragus aff. kopperi; Nesiotites aff. ponsi; Hypnomys onicensis; Rhinolophus aff. mehelyi; Athene vallgornerensis; Discoglossus; podarcis

Received 15 October 2013; Revised 26 November 2013; Accepted 8 May 2014

Citation: Díaz A., Bover P. and Alcover J.A. 2014. Fossil Vertebrate Database from Cova des Pas de Vallgornera (Llucmajor, Mallorca). International Journal of Speleology, 43 (2), 227-230. Tampa, FL (USA) ISSN 0392-6672 http://dx.doi.org/10.5038/1827-806X.43.2.10

\section{INTRODUCTION}

The goal of this paper consists on a general description of the DataBase built on the vertebrate palaeontological material obtained from Cova des Pas de Vallgornera (Llucmajor, Mallorca). It includes information on the site, collecting methods, recorded specimens, taxonomic identification, and conservation procedures. The dataset can be consulted in the Spanish GBIF node IPT:

http://www.gbif.es:8080/ipt/resource.do?r=vallgornera

http://data.gbif.org/datasets/resource/13091

\section{PROJECT DETAILS}

\section{Project title}

Excavació i estudi dels materials procedents de la Cova des Pas de Vallgornera (Llucmajor, Mallorca). Primera fase.

\section{Personnel}

Pere Bover (leader of the Project), Josep Antoni Alcover, Àlex Valenzuela.

\section{Funding}

Consell Insular de Mallorca [infrastructure funding]; IMEDEA (UIB-CSIC) [expedition funding]; Research Project CGL2012-38087 (Dirección General de Investigación Científica y Técnica, Spanish Ministerio de Economía y Competitividad) [research funding].

\section{TAXONOMIC COVERAGE}

\section{General taxonomic coverage description}

Most of the taxa from CPV are Mammalia (97.1\% of the catalogued items) followed by Aves (1.9\%), Reptilia $(0.8 \%)$ and Amphibia (0.2\%). It is worth mentioning here that the data set contains the type material of an extinct species of little owl from the Early Pleistocene of Mallorca (Athene vallgornerensis Guerra et al., 2012).

The collection includes 23 taxa and $97.5 \%$ of the specimens are identified at a species level. Myotragus aff. Kopperi is the most represented species in the database (897 catalogued items). The preservation of material is very good, allowing even detailed analyses on the teeth replacement and morphology using computerised tomography scan (Jordana et al., 2013). 
Class

Mammalia, Aves, Reptilia, Amphibia.

\section{Order}

Cetartiodactyla, Rodentia, Eulipotyphla, Chiroptera, Anseriformes, Falconiformes, Gruiformes, Charadriiformes, Columbiformes, Strigiformes, Passeriformes, Squamata, Anura.

\section{Family}

Bovidae, Gliridae, Soricidae, Vespertilionidae, Rhinolophidae, Anatidae, Accipitridae, Falconidae, Rallidae, Scolopacidae, Columbidae, Tytonidae, Strigidae, Corvidae, Fringillidae, Turdidae, Lacertidae, Discoglossidae.

\section{Genus}

Myotragus, Nesiotites, Hypnomys, Rhinolophus, Pipistrellus, Accipiter, cf. Gyps, Falco, Aegypius, Crex, Scolopax, Columba, Tyto, Athene, Corvus, Turdus, Pica, Podarcis, Discoglossus.

\section{Species}

Myotragus aff. kopperi, Hypnomys onicensis, Nesiotites aff. ponsi, Rhinolophus aff. mehelyi, Athene vallgornerensis, Pica mourerae, Columba palumbus, Accipiter nisus, Tyto balearica, Scolopax rusticola.

\section{Spatial and temporal coverage}

\section{General spatial coverage}

Cova des Pas de Vallgornera is an extensive maze cave (more than $70 \mathrm{~km}$ ) located on the south coast of Mallorca (Balearic Islands). Coordinates of the CPV entrance: $39^{\circ} 22^{\prime} 0^{\prime \prime} \mathrm{N}, 2^{\circ} 52^{\prime} 25^{\prime \prime} \mathrm{E}$, Datum: WGS84. It is considered one of the 30 longest caves in the world. It was discovered in 1968 in the course of a drilling carried out for the construction of a cesspit. CPV is the longest karstic system currently known in the Balearics. The fossiliferous deposit is located at the end of a passage known as Galeria del Tragus and Sala del Col-lapse. For a more extensive description see Merino et al. (2011, 2014) and Bover et al. (2014). The cave is under protection by the Balearic Conselleria de Medi Ambient, the Ministry of Environment of the Government of the Balearic Islands. It was declared Site of Community Importance within the Natura 2000 Network (European Council Directive 92/43/ EEC, no. ES5310049).

\section{Global Coordinates}

$39^{\circ} 8^{\prime} 24^{\prime \prime} \mathrm{N}$ and $39^{\circ} 36^{\prime} 36^{\prime \prime N}$ Latitude; $2^{\circ} 31^{\prime} 12$ ' $\mathrm{E}$ and 3॰8'60"E Longitude

Temporal coverage

Early Pleistocene (see Bover et al., 2014)

\section{Recovery dates}

2006; $9^{\text {th }}$ May 2009; 28 ${ }^{\text {th }}$ May $2010-30^{\text {th }}$ May 2010
After collection, the material was packed in protected containers that were carried outside the cave by a group of volunteers. The fossils have been identified by taxonomists of the IMEDEA (Pere Bover, Carmen Guerra and Josep Antoni Alcover), the University of the Basque Country - Euskal Herriko Unibertsitatea (Juan Rofes) and the Universidad de Zaragoza (Gloria Cuenca-Bescós).

The skeletal remains of Myotragus from CPV were generally in good preservation state. Most of bones are complete. From a conservation and restoration point of view, major issues are related to sediment presence. This sediment, which partially or fully covers some bones, can be present as: 1) a thin layer of calcium carbonate (less than $5 \mathrm{~mm}$ thick), or 2) as thick concretions, covering both the bone and the surrounding soft or hard clay. There is a number of cracked and broken bones. Some of these bones have been consolidated with acrylic resin (Paraloid B-67), and attached with nitrocellulose adhesive (Imedio). Some bones (like humeri and femora) have a more fragile consistency (with some powdering traces in both fracture plans and spongy tissue), while other bones, like jaws and metapodials, are very well preserved (they are very compact and without powdering traces).

The removal of the remains of sediment on the bones from CPV was mainly performed mechanically. Depending on the hardness and volume of sediment, vibroincisor, knife, punch and metal or wood poles were used. However, in many cases, the sediment was previously softened with distilled water and/or alcohol applied with brush or swab.

Only the parts of the bones with powder damage (especially in areas with cracks and fracture planes) were consolidated. In these cases an acrylic resin (Paraloid B-67) was used, diluted 5-10\% in acetone, which was applied with a brush or by dripping. Both cellulose nitrate (Imedio) and acrylic resin (Paraloid B-67) were used to hold the fragments. When the fragments to be glued were small or lightweight only Paraloid B-67 was used. A professional conservator (B. Font) performed all the conservation work.

All the material was numbered to be included at the IMEDEA Vertebrate Collection, and it is currently preserved in plastic bags, plastic boxes and cardboard boxes.

All the material has been digitalized and included in the IMEDEA vertebrate Collection. To guarantee the quality of the database in the GBIF network, the CPV dataset has been standardized following the standard Darwin Core version 1.2 for information exchange of natural history collections, and it has been later analysed to correct any possible error with the Darwin Test (an application to test and check data in the Darwin Core format, developed and supported by the Coordination Unit of the Spanish GBIF national node http://www.gbif.es/darwin test/Darwin Test. php; Ortega-Maqueda \& Pando, 2008). Among the checks performed, errors of omission, typographic, convention and consistency were analysed. 


\section{STUDY AND SAMPLING DESCRIPTION}

All the specimens were obtained in CPV. They were mainly obtained in Galeria del Tragus and the subsequent Sala del Collapse. The Galeria del Tragus is acceded through a $4 \mathrm{~h}$ underground trip, including one hour of swimming and $3 \mathrm{~h}$ walking, negotiating several narrow passages.

The Galeria del Tragus consists of a $270 \mathrm{~m}$ long, $10 \mathrm{~m}$ wide and $10 \mathrm{~m}$ high gallery, connected through a narrow passage to the Sala del Collapse, a hall c. 40 x 10 $\mathrm{m}$ sealed by a huge collapse of blocks and sediment, probably occurred shortly after the deposition of the bones. This gallery was in contact with the exterior during the Early Pleistocene, allowing the deposition of the bones at least partially through water transport.

The excavation campaign was carried out during 28$30^{\text {th }}$ May 2010. All the obtained specimens were labelled and protected. The material was mainly collected by hand and situated in the topographical survey indicating the number of the closest established section. Material partially covered by flowstone was extracted from the deposit through mechanical methods. Associated skeletons have been individualized.

\section{DATASETS}

\section{Parent collection identifier}

IMEDEA-PALEOVERT

\section{Collection name}

IMEDEA

\section{Collection identifier}

7f591d18-f762-11e1-a439-00145eb45e9a

\section{Specimen preservation method}

Dried specimens, when necessary consolidated with acrylic resin (Paraloid B-67), and attached with nitrocellulose adhesive.

\section{Curatorial unit}

1481 (FossilSpecimen)

\section{Object name of dataset}

Darwin Core Archive Fossil Vertebrate Database from Cova des Pas de Vallgornera (Llucmajor, Mallorca)

\section{Character encoding UTF-8}

\section{Format name}

Darwin Core Archive format

\section{Format version}

1.0

\section{Distribution}

http://www.gbif.es:8080/ipt/archive. do?r=vallgornera
Publication date of data

2013-09-30

\section{Language \\ Catalan}

Licenses of use

IMEDEA-PALEOVERT is available under Open Data Commons Attribution: http://www.opendatacommons. org/licenses/by/1.0/.

\section{Metadata language \\ English}

Date of metadata creation

2013-09-23

\section{Hierarchy level}

Dataset

\section{ACKNOWLEDGEMENT}

The excavation was possible thanks to the help and effort of a large group of cavers from the Balearic Federation of Speleology (FBE) and a large number of people have collaborated in the transport, conservation and study of the material. We should name here: Guillem Mulet, Antoni Mulet, Anders Kristofersson, Antoni Croix and Manolo Luque as cavers' leaders, Enric Alcover, Àlex Valenzuela and Carl Mehling, as part of the excavation team, Bernat Font as conservator, Carmen Guerra, Gloria CuencaBescós, and Juan Rofes as taxonomists, Helena Inglada as technical of the Direcció General de Patrimoni (responsible authority on Historical Heritage) of the Consell de Mallorca (Mallorcan Government), and Francesc Ruiz for his help to obtain sponsors. The Consell de Mallorca provided financial resources to build the bridge over the most delicate sector of the Galeria del Tragus. The Direcció General de Biodiversitat (responsible authority on Nature Management of the Balearic Government), and the Direcció General de Patrimoni permitted to carry out the excavation in the Cova des Pas de Vallgornera. The members of the Spanish GBIF node, especially Francisco Pando and Katia Cezón, helped us in the database migration process. The companies Oxidoc, Es Refugi, and Foracorda provided some equipment for the excavation team. Additional support was provided by Protección Civil España, Consejo Superior de Deportes, and Federación Española de Espeleología. One of the authors, PB, received support from a JAEDOC (CSIC) contract (Junta para la Ampliación de Estudios) during the excavation. This paper is included in the Research Project CGL2012-38087 (Dirección General de Investigación Científica y Técnica of the Spanish Ministerio de Economía y Competitividad). 


\section{REFERENCES}

Bover P., Valenzuela A., Guerra C., Rofes J., Alcover J.A., Ginés J., Fornós J.J., Cuenca-Bescós G. \& Merino A., 2014 - The Cova des Pas de Vallgornera (Llucmajor, Mallorca): an singular deposit containing an extraordinarily well preserved Early Pleistocene vertebrate fauna. International Journal of Speleology, 43 (2): 175-192. http://dx.doi.org/10.5038/1827-806X.43.2.6

Guerra C., Bover P. \& Alcover J.A., 2012 - A new species of extinct little owl from the Pleistocene of Mallorca (Balearic Islands). Journal of Ornithology, 152: 347354. http://dx.doi.org/10.1007/s10336-011-0749-3 Jordana X., Marín-Moratalla N., Moncunill-Solé B., Bover P., Alcover J.A. \& Köhler M., 2013 - First fossil evidence for the advance of replacement teeth coupled with life history evolution along an anagenetic mammalian lineage. PLoS ONE, 8 (7): e70743.

http:/ / dx.doi.org/10.1371/journal.pone.0070743
Merino A., Mulet A., Mulet G., Croix A., Kristofersson A., Gràcia, F. \& Perello M.A., 2014 - Cova des Pas de Vallgornera, (Mallorca, Spain): history of exploration and cave description. International Journal of Speleology, 43 (2): 95-104.

http://dx.doi.org/10.5038/1827-806X.43.2.1

Merino A., Mulet A., Mulet G., Croix A., Kristofersson A., Gràcia F., Ginés J. \& Fornós J.J., 2011 - La cova des Pas de Vallgornera (Llucmajor, Mallorca). La cavitat de major desenvolupament de les Illes Balears. Endins, 35/Monografies de la Societat d'Història Natural de les Balears, 17: 147-164.

Ortega-Maqueda I. \& Pando F., 2008 - DARWIN_TEST 3.3: Una aplicación para la validación y el chequeo de los datos en formato Darwincorev2 o Darwincore 1.4, http://www.gbif.es/Darwin test/Darwin test.php. Unidad de Coordinación de GBIF.ES, CSIC. Ministerio de Educación y Ciencia, España 